\title{
Vickers Hardness of Cast Commercially Pure Titanium and Ti-6Al-4V Alloy Submitted to Heat Treatments
}

\author{
Sicknan Soares da ROCHA ${ }^{1}$ \\ Gelson Luis ADABO ${ }^{1}$ \\ Guilherme Elias Pessanha HENRIQUES ${ }^{2}$ \\ Mauro Antônio de Arruda NÓBILO²
${ }^{1}$ Department of Dental Materials and Prosthodontics, Faculty of Dentistry of Araraquara, São Paulo State University, Araraquara, SP, Brazil
${ }^{2}$ Department of Periodontology and Prosthodontics, Faculty of Dentistry of Piracicaba, State University of Campinas, Piracicaba, SP, Brazil

\begin{abstract}
The purpose of this study was to evaluate the effect of heat treatments on the Vickers hardness of commercially pure titanium and Ti6Al-4V cast alloys. Six-millimeter-diameter cylindrical specimens were cast in a Rematitan System. Commercially pure titanium and Ti-6Al-4V alloy specimens were randomly assigned to 3 groups $(n=10)$ that received the following heat treatments: control (no heat treatment); treatment 1 (T1): heating at $750^{\circ} \mathrm{C}$ for $2 \mathrm{~h}$; and treatment $2(\mathrm{~T} 2)$ : annealing at $955^{\circ} \mathrm{C}$ for $1 \mathrm{~h}$ and aging at $620^{\circ} \mathrm{C}$ for $2 \mathrm{~h}$. After heat treatments, the specimens were embedded in acrylic resin and their surface was ground and polished and hardness was measured. Vickers hardness means (VHN) and standard deviations were analyzed statistically by Kruskal-Wallis test at 5\% significance level. For commercially pure titanium, Vickers hardness means of group T2 $(259.90 \mathrm{VHN})$ was significantly higher than those of the other groups (control - 200.26 VHN and T1 - 202.23 VHN), which presented similar hardness means to each other (p $>0.05$ ). For Ti-6Al-4V alloy, statistically significant differences were observed among the three groups: T2 (369.08 VHN), T1 (351.94 VHN) and control (340.51 VHN) $(\mathrm{p}<0.05)$. The results demonstrated different hardness of CP Ti and Ti-6Al-4V when different heat treatments were used. For $\mathrm{CP} \mathrm{Ti}$, VHN means of T2 group was remarkably higher than those of control and T1 group, which showed similar VHN means to each other. For Ti-6Al-4V alloy, however, VHN means recorded for each group may be presented as follows: T2>T1>control.
\end{abstract}

Key Words: titanium, heat treatments, Vickers hardness.

\section{INTRODUCTION}

Titanium has been increasingly used in dental applications because of its excellent biocompatibility (1), high corrosion resistance, low density, high strength/ weight ratio, high ductility, low thermal conductivity and adequate mechanical properties (2-5). The most commonly used titanium alloy is Ti-6Al-4V, due to its optimal mechanical characteristics $(6,7)$.

Titanium has much lower density $\left(4.2 \mathrm{~g} / \mathrm{cm}^{3}\right)$ than conventional alloys such as cobalt-chromium (8.9 $\left.\mathrm{g} / \mathrm{cm}^{3}\right)$ and gold $\left(19.3 \mathrm{~g} / \mathrm{cm}^{3}\right)$. Low density associated with a high melting point (approximately $1720^{\circ} \mathrm{C}$ for commercially pure titanium - CP Ti) and high chemical reactivity of titanium with elements in the investment $(3,8)$ require special casting machines $(4,9)$.

At room temperature, $\mathrm{CP} \mathrm{Ti}$ has a hexagonal close-packed crystal structure, which is referred to as the "alpha" phase. At $883^{\circ} \mathrm{C}$, this structure transforms into a body-centered cubic crystal structure, called the "beta" phase. These phase changes can directly influence titanium properties.

Because of the high melting point of titanium and the investment mold with burnout temperatures below $800^{\circ} \mathrm{C}$, the large heat gradient through which titanium must pass may cause a great alteration in its mechanical properties (10). Studies have shown that substantial benefits in mechanical properties can be achieved when

Correspondence: Prof. Dr. Gelson Luis Adabo, Departamento de Materiais Odontológicos e Prótese, FOAr/UNESP, Rua Humaitá, 1680, Caixa Postal: 331, 14801-903 Araraquara, SP, Brasil. Tel: +55-16-201-6406. Fax: +55-16-201-6406. e-mail: adabo@foar.unesp.br 
these materials undergoes heat treatments (11-16).

For $\mathrm{CP} \mathrm{Ti}$ and titanium alloys, heat treatments can be employed to reduce the residual stresses that develop during casting, a process called stress relieving, as well as to optimize specific properties such tensile and fatigue strengths and hardness (16).

In view of the limited data available describing the efficiency of heat treatments in cast titanium structures, the purpose of this study was to evaluate the effect of heat treatments on the Vickers hardness of CP Ti and Ti6Al-4V cast alloys.

\section{MATERIAL AND METHODS}

CP Ti and Ti-6Al-4V metals were manufactured by RMI Titanium Company (Niles, OH, USA). Compositions are given in Table 1. Six-millimeterdiameter cylindrical wax specimens were placed in the dental casting investment (Rematitan Plus; Dentaurum J. P. Winkelstroeter KG, Pforzheim, Germany) and mixed and fired according to the manufacturer's instructions. The molds were inserted in the Rematitan System casting machine (Dentaurum J.P. Winkelstroeter $\mathrm{KG})$, which consisted of 2 chambers: an upper melting chamber that houses a copper crucible and a tungsten electrode, and a lower casting chamber where the invested mold is placed.

Castings were divested and blasted with $50-\mu \mathrm{m}$ aluminum-oxide particle airborne. The specimens were separated from the sprues using a precision saw (Isomet 1000; Buehler, Lake Bluff, IL, USA).

The CP Ti and Ti-6Al-4V alloy specimens were randomly assigned to 3 groups $(\mathrm{n}=10)$ according to the treatment accomplished: control: no heat treatment; treatment $1(\mathrm{~T} 1)$ : heating at $750^{\circ} \mathrm{C}$ for $2 \mathrm{~h}$; treatment 2 (T2): annealing at $955^{\circ} \mathrm{C}$ for $1 \mathrm{~h}$ and aging at $620^{\circ} \mathrm{C}$ for $2 \mathrm{~h}$. Heating and cooling were carried out in a furnace (FV-1 MP, E. D. G. Equipments and Controls Ltd., São Carlos, SP, Brazil) in argon atmosphere.

After heat treatments, the specimens were embedded in acrylic resin (Dencor Clássico Produtos Odontológicos Ltda, São Paulo, SP Brazil). A polishing machine (Metaserv 2000, Buehler UK Ltd, Coventry, West Midlands, England) was used to grind and polish the surface with sandpaper (Carbimet Paper Discs, Buehler) (300, 400, 600 and 1200 grits) and alumina paste (0.5- $\mu \mathrm{m}$ particle size) (Alpha Micropolish, Buehler).

Vickers hardness was measured using a 500-g load and a 15-s loading time (Micromet 2100, Buehler). Vickers hardness means (VHN) and standard deviations were analyzed statistically by Kruskal-Wallis non-parametric test at 5\% significance level, for each metal.

\section{RESULTS}

Table 2 shows Vickers hardness means ( \pm SD) for each experimental condition and metal. For $\mathrm{CP} \mathrm{Ti}$, VHN means of T2 group was significantly higher

Table 1. Composition (\%) of the commercially pure titanium (CP Ti) and Ti-6Al-4V alloy.

\begin{tabular}{lcccccccc}
\hline & $\mathrm{N}$ & $\mathrm{C}$ & $\mathrm{H}$ & $\mathrm{Fe}$ & $\mathrm{O}$ & $\mathrm{Al}$ & $\mathrm{V}$ & $\mathrm{Ti}$ \\
\hline CP Ti & 0.02 & 0.08 & 0.007 & 0.18 & 0.15 & - & - & Balanced \\
Ti-6Al-4V & 0.02 & 0.01 & 0.003 & 0.22 & 0.17 & 6.2 & 3.8 & Balanced \\
\hline
\end{tabular}

Table 2. Vickers hardness $(\mathrm{VHN})$ means $( \pm \mathrm{SD})$ for commercially pure titanium (CP Ti) and Ti-6Al-4V alloys according to the heat treatment performed.

\begin{tabular}{lccc}
\hline Materials & Control & T1 & T2 \\
& & & \\
\hline CP Ti & $200.26 \pm 5.43 \mathrm{a}$ & $202.23 \pm 10.69 \mathrm{a}$ & $259.90 \pm 23.26 \mathrm{~b}$ \\
Ti-6Al-4V & $340.51 \pm 6.20 \mathrm{c}$ & $351.94 \pm 7.85 \mathrm{~d}$ & $369.08 \pm 10.37 \mathrm{e}$ \\
\hline
\end{tabular}

Different letters indicate statistically significant difference at $5 \%(\mathrm{p}<0.05)$. 
$(p<0.05)$ than those of the other groups. VHN means of control and $\mathrm{T} 1$ groups did not differ statistically to each other ( $p>0.05$ ). Regarding Ti-6Al-4V alloy, statistically significant difference was observed among the three groups $(\mathrm{T} 2>\mathrm{T} 1>$ control $)(\mathrm{p}<0.05)$.

\section{DISCUSSION}

Several studies have attempted to characterize properties of pure titanium and titanium alloys after treatments involving different heating times and temperatures, as well as diverse cooling methods (11-16).

In the control group (no heat treatment), the Vickers hardness means recorded for the Ti-6Al-4V alloy $(340.51 \mathrm{VHN})$ was remarkably higher than that of the CP Ti (200.26 VHN) and these values are similar to those reported in previous investigations with both metals $(4,9,17-19)$.

The heat treatments evaluated $\left[750^{\circ} \mathrm{C}\right.$ for $2 \mathrm{~h}$ (T1) and annealing at $955^{\circ} \mathrm{C}$ for $1 \mathrm{~h}$ followed by aging at $620^{\circ} \mathrm{C}$ for $2 \mathrm{~h}$ (T2)], yielded different effects on Vickers hardness means recorded for each type of metal.

For CP Ti, Vickers hardness means of T2 group $(259.90 \mathrm{VHN})$ was significantly higher than those of the other groups (T1 - 202.23 VHN; control - 200.26 VHN), which presented similar means. It has been shown that the hardness of specimens submitted to heat treatment results from the equilibrium between the alpha and beta phases at the treatment temperature, the compositions of these phases and the decomposition of martensite during the quench (12). Regarding the effect of temperature, it was observed that for $\mathrm{CP} \mathrm{Ti}$ (alpha structure), T1 treatment temperature $\left(750^{\circ} \mathrm{C}\right.$ for $\left.2 \mathrm{~h}\right)$ was below that of the transformation phase temperature $\left(883^{\circ} \mathrm{C}\right)$, which may explain the lack of significant difference between control group (no heat treatment) and $\mathrm{T} 1$ group. In contrast, T2 (1-h annealing at $955^{\circ} \mathrm{C}$ and 2-h aging at $620^{\circ} \mathrm{C}$ ) employed a temperature of above $883^{\circ} \mathrm{C}$, at which the transformation of the hexagonal close-packed crystal structure (alpha phase) to the body-centered cubic structure (beta phase) occurs. This significantly increased the hardness of the material, possibly as a result of alterations in the microstructure.

For Ti-6Al-4V alloy, statistically significant differences were observed among the three groups: T2 $(369.08 \mathrm{VHN})>\mathrm{T} 1(351.94 \mathrm{VHN})>$ control $(340.51$ VHN). The higher Vickers hardness means of T2 group (age hardening) is consistent with the results of a previous study (12), which evaluated the effects of heat treatments on three titanium alloys (Ti-6Al-4V, Ti-6Al6V-2Sn and Ti-8Al-1Mo-1 V) and observed higher hardness values for all alloys after aging in the alpha-beta region, provided that the beta transformed martensitically during the quench.

An important aspect that might have contributed to the increased hardness of both metals with age hardening treatment $\left(\mathrm{T} 2\right.$; temperature above $\left.800^{\circ} \mathrm{C}\right)$ is the cooling method used. In present study, the slow cooling method was employed $\left(7^{\circ} \mathrm{C} / \mathrm{min}\right.$ in furnace), which permits the formation of an ordered structure and a higher strength and hardness at room temperature, but a lower ductility.

Several variables, such as alloy phase (alpha, alpha-beta or beta), treatment temperature in the field of the alpha-beta or beta phase, temperature duration as well as cooling rate or method, can determine the mechanical behavior of titanium alloys submitted to heat treatments. Threfore, it is difficult to compare the results of this study to those of other studies. In addition, available data about heat treatments in titanium are very limited. Further studies, including fatigue mechanical trials, are required to determine suitable treatment conditions applicable to cast titanium structures, with the aim of improving the chemical, physical, mechanical and biological properties of titanium casts, as well as achieving satisfactory clinical longevity.

Within the limits of this study, it may be concluded that the use of different heat treatments resulted in different hardness means of commercially pure titanium and Ti-6Al-4V. For commercially pure titanium, VHN means of T2 group was remarkably higher than those of control and T1 group, which showed similar VHN means to each other. For Ti-6Al-4V alloy, however, VHN means recorded for each group may be presented as follows: $\mathrm{T} 2>\mathrm{T} 1>$ control.

\section{RESUMO}

O objetivo deste estudo foi avaliar o efeito de tratamentos térmicos na dureza Vickers do titânio comercialmente puro e da liga Ti6Al-4V. Corpos-de-prova cilíndricos com $6 \mathrm{~mm}$ de diâmetro foram fundidos no sistema Rematitan. Os corpos-de-prova de titânio comercialmente puro e da liga Ti-6Al-4V foram divididos aleatoriamente em 3 grupos $(n=10)$ : controle (sem tratamento térmico); tratamento 1 (T1): aquecido a $750^{\circ} \mathrm{C}$ por $2 \mathrm{~h}$; tratamento 2 (T2): aquecido a $955^{\circ} \mathrm{C}$ por $1 \mathrm{~h}$ e envelhecido a $620^{\circ} \mathrm{C}$ por $2 \mathrm{~h}$. Após os tratamentos térmicos, os corpos-de-prova foram incluídos em resina acrílica, a superfície foi regularizada e polida, 
e a dureza foi mensurada. As médias de dureza Vickers (VHN) e os desvios padrão foram analisados estatisticamente usando o teste de Kruskal-Wallis com nível de significância a 5\%. Para o titânio comercialmente puro, a média de dureza do grupo T2 $(259,90 \mathrm{VHN})$ foi significativamente maior que os outros grupos (controle-200,26 VHN e T1-202,23 VHN) $(\mathrm{p}<0,05)$, que apresentaram valores médios similares $(p>0,05)$. Para a liga Ti$6 \mathrm{Al}-4 \mathrm{~V}$, diferenças estatisticamente significantes foram observadas entre os três grupos: T2 $(369,08 \mathrm{VHN}), \mathrm{T} 1 \mathrm{(351,94}$ VHN) e controle $(340,51 \mathrm{VHN})(\mathrm{p}<0,05)$. Os resultados demonstraram diferente comportamento de dureza do titânio comercialmente puro e da liga Ti-6Al-4V quando diferentes tratamentos foram usados. Para o titânio comercialmente puro, a média de VHN grupo T2 foi consideravelmente maior que as médias dos grupos controle e T1, os quais demonstraram médias similares entre si. Para a liga Ti-6Al-4V, entretanto, a média de VHN registrada para cada grupo pode ser apresentada da seguinte maneira: $\mathrm{T} 2>\mathrm{T} 1>$ controle.

\section{REFERENCES}

1. Jones TK, Hansen CA, Singer MT, Kessler HP. Dental implications of nickel hypersensitivity. J Prosthet Dent 1986;56:507-509.

2. Wang RR, Boyle AM. A simple method for inspection of porosity in titanium castings. J Prosthet Dent 1993;70:275276.

3. Ohkubo C, Watanabe I, Ford JP, Nakajima H, Hosoi T, Okabe T. The machinability of cast titanium and Ti-6Al-4V. Biomaterials 2000;21:421-428.

4. Zinelis S. Effect of pressure of helium, argon, krypton, and xenon on the porosity, microstructure, and mechanical properties of commercially pure titanium castings. J Prosthet Dent 2000;84:575-582.

5. Jang KS, Youn SJ, Kim YS. Comparison of castability and surface roughness of commercially pure titanium and cobaltchromium denture frameworks. J Prosthet Dent 2001;86:9398.

6. Syverud M, Okabe T, Hero H. Casting of Ti-6Al-4V alloy compared with pure Ti in an Ar-arc casting machine. Eur J
Oral Sci 1995;103:327-330.

7. Wang RR, Fenton A. Titanium for prosthodontic applications: A review of the literature. Quintessence Int 1996;27:401-408.

8. Dimitris E, Zinelis S, Papadopoulos T. The effect of investment material type on the contamination zone and mechanical properties of commercially pure titanium castings. J Prosthet Dent 2005;94:539-548.

9. Taira M, Moser JB, Greener EH. Studies of Ti alloys for dental casting. Dent Mater 1989;5:45-50.

10. Lautenschlager E, Monaghan P. Titanium and titanium alloys as dental materials. Int Dent J 1993;43:245-253.

11. Ahmed T, Rack HJ. Phase transformations during cooling in alpha + beta titanium alloys. Mater Sci Eng 1998;A243:206211.

12. Fopiano PJ, Hickey Jr CF. Comparison of the heat treatment responses of three commercial titanium alloys. J Test Eval 1973;1:514-519.

13. Markovsky PE. Improvement of structure and mechanical properties of cast titanium alloys using rapid heat treatment. Mater Sci Eng 1995;A190:L9-L12.

14. Simbi DJ, Scully JC. The effect of residual interstitial elements and iron on mechanical properties of commercially pure titanium. Mater Lett 1996;26:35-39.

15. Bourassa PL, Yue S, Bobyn JD. The effect of heat treatment on the fatigue strength of microknurled Ti-6Al-4V. J Biomed Mater Res 1997;37:291-300.

16. Weiss I, Semiatin SL. Thermomechanical processing of alpha titanium alloys - an overview. Mater Sci Eng 1999;A263:243256.

17. Sunnerkrantz PA, Syverud M, Hero H. Effect of casting atmosphere on the quality of Ti crowns. Scand J Dent Res 1990;98:268-272.

18. Tajima K, Matsuda S, Kitajima S, Yodoyama Y, Kakigawa H, Kozono Y. Efficacy of gas purging for titanium casting. Dent Mater J 1994;13:206-213.

19. Trillo EA, Ortiz C, Dickerson P, Villa R, Stafford SW, Murr LE. Evaluation of mechanical and corrosion biocompatibility of TiTa alloys. J Mater Sci Mater Med 2001;12:283-292.

Accepted September 21, 2004 